\title{
入院を必要とした外国人旅行者の救急疾患に対する 医療の現状と問題点
}

\author{
尾世川正明 ${ }^{1}$ 森尾比呂志 ${ }^{2}$ 野本 和宏 $^{3}$ 西澤 正彦 $^{4}$ \\ 貞店 智仁 1
}

\begin{abstract}
要旨 成田赤十字病院は新東京国際空港に近接しており, 外国人旅行者の救急患者を診療する機 会が多い。本報は当院救命救急センターに 1993 年から 2000 年までの 8 年間に入院した旅行中の 外国人救急患者 82 人（男性 50 人，女性 32 人：年齢 $15-82$ 歳, 平均年齢 47.7 歳）を検討した。患 者の国籍は米国が 31 人と最も多く，次いで東アジア 29 人で，患者の国籍は 22 か国に及んだ。 55 人は英語を話したが, 英語を解さない 24 人とはコミュニケーションをとることが最も深刻な問題 であった。このようなケースでは, 病歴聴取, 治療上のインフォームドコンセントの取得, 病状 説明などが入院時ほとんど不可能であった。疾患の内訳は, 消化管疾患 (消化管出血, 穿孔, 腸 閉塞, 急性虫垂炎など) $22 \%$, 循環器疾患 (急性心筋梗塞, 心不全) $16 \%$, 外傷 $18 \%$, 中枢神経系 疾患 (脳血管障害, 廎㾍など) $15 \%$, 呼吸器疾患（呼吸不全，肺炎など） $7 \%$, その他の疾患 $22 \%$ であった。18人 $(22 \%)$ の患者が ICU/CCUに入室した。転帰は 62 人で軽快, 不変が 10 人, 簡易 な処置で帰国した者 3 人, 死亡 7 人 $(9 \%)$ であった。ICU/CCU 入室率, 死亡率ともこの時期 の救命救急センター入院患者よりも高かったが, 多くの患者が可及的早期の退院と帰国を希望し た。そのため入院期間は短く, 3 日以下が 36 人，4-10日が 19 人，11-20日が 15 人で, 全体の平均 在院日数は 10.8 日であった。帰国時, 病状のため医療者（医師および看護婦）の付き添いを要し たケースが 12 人, 家族もしくは関係者の援助を要したのは 20 人であった。鹵国時, 13 人は車椅 子を使用し，7 人はストレッチャーで搬送された。外国人旅行者の救急医療は言語や医療費の問 題に加えて, 早期退院や早期帰国などの要望を実現するため, 病院とスタッフに特例的な努力を 強いる。行政は，このような医療を担当する病院に効果的援助を検討するべきである。

(日救急医会誌 $2002 ; 13: 703-10)$

キーワード : 外国人旅行者, 救急, 空港
\end{abstract}

\section{はじめに}

近年，人的国際交流が盛んになり，わが国でも航 空機を利用して出入国する外国人旅行者の数は増加 し，年間約600万人となっている1)。国外への旅行者

Present medical practice and problems in emergency disease in foreign travelers requiring hospital admission

1成田赤十字病院救命救急センター ${ }^{2}$ 同内科 ${ }^{3}$ 同脳神経外科 4 同外科

著者連絡先：干 286-8523 成田市飯田町 90-1

原稿受理日：2002 年 3 月 8 日 (02-021)
の疾病に関しては，発展途上国への旅行のみならず 先進国を旅行中に起こる疾患の研究報告 ${ }^{2,3)}$ や, 航空 機内で増悪する疾病に間する総説 ${ }^{4)}$ や研究 5,6$)$ など がある。一方，わが国の外国人旅行者に対する救急 診療に関しては，そのような医学的問題以外に社会 的問題すなわち言語の問題や，不法滞在，医療費お よび帰国費用の問題など様々な困難な問題があるこ とが指摘されている ${ }^{7-9)}$ 。

新東京国際空港に隣接する成田赤十字病院救命救 急センターでは, センター開設以来，航空機を利用 する外国人旅行者の重症救急患者を数多く受け入れ 
てきた。そこで当救命救急センターで入院診療を 行った外国人旅行者の救急患者について, その国籍, 使用言語，疾患分布，入院期間，帰国方法の実態な どを分析し，外国人旅行者に対する救急診療の諸問 題を検討した。

\section{対象と方法}

1993 年 1 月から 2000 年 12 月までの 8 年間に, 成 田赤十字病院救命救急センターに入院した外国籍の 救急患者 82 人について診療録の記載に基づき，患者 背景, 疾患分布, 入院期間, 転帰, 帰国方法, 医療 費支払方法などを検討した。わが国に 2 か月以上滞 在中の外国人や，日本人で外国に住む者は今回除外 した。またセンター以外の病棟（小児科，産科，精 神科病棟など）に入院した救急患者や，当センター に救急受診したが外来診療のみを受診した者も除い た。

外国人旅行者と一般救急患者との比較のため，同 期間中の当院救急患者数, 救急入院数, 当院救命救 急センターの全患者数, ICU/CCUの入室者数, 死亡 者数を当院医事課集計から調査した。さらに同期間 中の新東京国際空港を利用して出入国した国別外国 人数を，法務省による統計資料に基づき集計した ${ }^{11}$ 。 2000年度外国人救急入院患者医療費の収納状況に ついては当院の年度会計報告によった。推計学的検 討には $\chi^{2}$ 検定を用いた。

\section{結＼cjkstart果}

対象となった患者 82 人は，この期間に当院が扱っ た救急患者総数 208,378 人の $0.039 \%$ に当たり，また 当院救急救命センターに入院した 12,160 人の $0.67 \%$ に当たる。年齢は15歳から82歳と広範に分布し平均 年齢は47.7歳で，性別は男性 50 人，女性 32 人であっ た。このうち一般旅行者は64人で, 航空機乗務員 13 人，密入国などの犯罪者が 5 人いた。また一般旅行 者の中には移民者，もしくは家族の移民先で暮らす 予定の者が 5 人いた。

緊急な入院や診療に際しては通常家族などの同伴

\begin{tabular}{|c|c|c|}
\hline Nationality & No. & \\
\hline U.S. & 31 & $(38 \%)$ \\
\hline \multicolumn{3}{|l|}{ East Asia } \\
\hline Thailand & 7 & \multirow{8}{*}{$\begin{array}{c}29 \\
(35 \%)\end{array}$} \\
\hline Korea & 6 & \\
\hline Philippines & 4 & \\
\hline Taiwan & 4 & \\
\hline Malaysia & 3 & \\
\hline Indonesia & 2 & \\
\hline Republic of China & 2 & \\
\hline Singapore & 1 & \\
\hline \multicolumn{3}{|l|}{ Other } \\
\hline Great Britain & 5 & \multirow{4}{*}{$\begin{array}{c}22 \\
(27 \%)\end{array}$} \\
\hline India & 5 & \\
\hline Australia & 2 & \\
\hline $\begin{array}{l}\text { Brunei, Canada, France, } \\
\text { Germany, Iran, Peru, } \\
\text { Netherlands, Russia, } \\
\text { New Zealand, Spain, }\end{array}$ & 1 & \\
\hline
\end{tabular}

者がいることが望ましいが，来院時家族が同伴して いた者は 19 人 $(23 \%)$ のみで, 関係者の同伴した者 13 人を加えても，患者サイドで病状説明を受け，治 療選択における意志決定に協力できる者がいたのは 32 人（39\%）のみであった。

国籍はアメリカ合衆国が 31 人（38\%）といちばん 多く，次いで夕イ，韓国，フィリピンなどの東アジ ア人が 29 人 $(35 \%)$ であった。入院した患者の国籍 は総計 22 か国に及んだ（Table 1）。この 8 年間に新 東京国際空港で出入国した外国人約 3,545 万人の国 籍をみると，アメリカ人が $21.3 \%$ ，韓国人が $21.8 \%$ を 占めて共に多く, 以下台湾籍中国人 $1.3 \%$, 中国人 $6.8 \%$, 英国人 $5.3 \%$, フィリピン人 $3.4 \%$ ，夕イ人 $2.0 \%$, インドネシア人 $1.0 \%$ などであり ${ }^{1)}$ ，当院入院患者の 国籍別比率は空港で出入国する旅行者の国籍別比率 にほぼ相関していたが，韓国人患者は旅行者数に比 して少なかった。

診療に際し使用した言語に関しては，全82人のう ち英語を母語とする者が 35 人 (43\%)，英語で意思疎 通可能だった者は 20 人 ( $24 \%)$, 英語で意思疎通不可 
Table 2. Language.

$\begin{array}{lcc}\text { Communication in English } & & \\ \text { as mother tongue } & 35 & (43 \%) \\ \text { communicate } & 20 & (24 \%) \\ \text { not communicate } & 24 & (29 \%) \\ \text { unconscious } & 3 & (4 \%) \\ \text { Total } & 82 & \\ \text { Nationality of patients speaking neither English nor Japanese } \\ \text { Korean } & 5 & 3 \\ \text { Chinese } & 2 & \\ \text { Indonesian } & 2 & \\ \text { Thai } & \\ \text { Vietnamese-American } & \\ \text { Philippine-American } & \\ \text { Russian-Australian } & \\ \text { French, Indian, Peruvian } & \\ \text { Malaysian } & \\ \text { Total } & \end{array}$

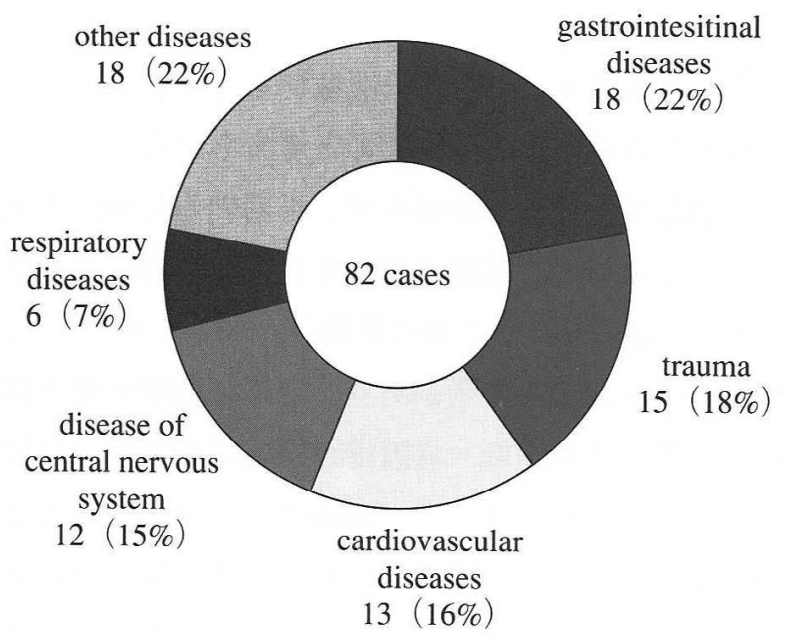

Fig. 1. Disease distribution.

能だった者が 24 人（29\%）に及んだ。3 例は意識不 明のまま経過し，本人との意思疎通はできなかった (Table 2)。英語で意思疎通不可能だった 24 人のうち 5 人は, 多少の日本語会話が可能であったが不十分 で，残る19人はまったく日本語ができないため病歴 聴取などに苦慮した。英語も日本語も話さない者は 韓国人，中国人，インドネシア人，タイ人，ベトナ ムやフィリピン系のアメリカ人など東アジア出身者 に多くみられた（Table 2)。
Table 3. Diagnosis.

\begin{tabular}{lc}
\hline Diagnosis & No. of Case \\
\hline Trauma & 15 \\
Acute myocardial infarction & 7 \\
Heart failure & 5 \\
Cerebral vascular accident & 5 \\
Perforation of digestive tract & 4 \\
Acute appendicitis & 4 \\
Epilepsy & 4 \\
CPAOA & 3 \\
Respiratory failure & 3 \\
GI tract bleeding & 3 \\
Drug intoxication & 3 \\
Malignancy & 2 \\
Ileus & 2 \\
Renal failure/Uremia & 2 \\
Diabctic ketoacidosis & 2 \\
Other & 18 \\
\hline
\end{tabular}

入院の原因となった疾患の分類は, 消化器疾患が $22 \%$ と多く，以下外傷 $18 \%$, 循環器疾患 $16 \%$, 中枢 神経系疾患 15\% と続いた（Fig. 1）。

外傷 15 人のうちには飛行機が乱気流により摇れた ために転倒した者，1日だけの滞在にもかかわらず慣 れない道路でジョギング中に交通事故にあった者な どがあった。

疾患別では急性心筋梗塞 7 人, 心不全 5 人, 脳血 管障害 5 人，消化管穿孔 4 人，急性虫垂炎 4 人，癲 疰発作 4 人などが上位を占めていた (Table 3)。ICU/ CCUに入室して治療を行った者は 18 人 $(22 \%)$ に及 んだ。この期間中の救命救急センター入院患者全体 12,160 人では ICU/CCU 入室を要した者が 1,247 人 （10\%）であり，外国人旅行者の患者群には有意に ICU/CCUに入室した重症者が多かった $(\mathrm{p}<0.001)$ 。外 国人救急患者の中には悪性疾患末期で故国への強い 帰国意志から旅行に及び，旅行途中で病態が悪化し た者，慢性呼吸不全が飛行巾に機内の気压の低下や 空気の乾燥などによって増恶した者 ${ }^{10,11)}$ ，慢性腎不 全の持病がありながら，それを知らずにあるいは十 分に考慮せず旅行し病態が悪化した者がいた。なお， 長時間の航空機旅行で注意すべき疾患である肺血栓 
尾世川正明，他

Table 4. Place of onset and emergency landing at the New Tokyo International Airport.

\begin{tabular}{lcc}
\hline In airplane & 36 & $(44 \%)$ \\
In airport & 17 & $(21 \%)$ \\
In city (in hotel) & 25 & $(30 \%)$ \\
Before departure & 4 & $(5 \%)$ \\
Total & 82 & \\
Emergency landing & 11 & $(13 \%)$ \\
\hline
\end{tabular}

Table 5. Outcome and patient condition at discharge.

\begin{tabular}{lcc}
$\begin{array}{l}\text { Left for home country } \\
\text { after only simple treatment }\end{array}$ & 3 & $(4 \%)$ \\
$\begin{array}{l}\text { Left for home country } \\
\text { without remarkable amelioration }\end{array}$ & 10 & $(12 \%)$ \\
$\begin{array}{l}\text { Left for home country } \\
\text { after remarkable amelioration }\end{array}$ & 62 & $(76 \%)$ \\
Died in hospital & 7 & $(9 \%)$ \\
\hline
\end{tabular}

塞栓症 ${ }^{12,13)}$ はこの患者群には含まれていなかった。

疾患の発症場所としては航空機内 36 人 $(44 \%)$ ，空 港内 17 人 $(21 \%)$, 短期滞在中の市内のホテルや道路 上が 25 人 $(30 \%)$ であった。また出発地からすでに 入院の原因となった疾患を発症していた者が 4 人 （5\%）みられた。なお航空機内での発症により，本 来目的地ではなかった新東京国際空港に緊急着陸し, 当院に搬送された者が11人（13\%）いた（Table 4）。

入院後の患者の転帰は，簡易な応急処置のみで帰 国した者 3 人 $(4 \%)$, 治療途中もしくは病態不変の まま帰国あるいは他院へ転院となった者 10 人 $(12 \%)$ ，軽快して帰国した者 62 人 $(76 \%)$ ，当院で死 亡した者 7 人 $(9 \%)$ であった（Table 5)。この期間 中の救命救急センター入院患者全体での死亡率は 4.4\%であり，この患者群での死亡率は高い傾向に あったが有意ではなかった。

入院期間は 3 日以下 36 人 $(44 \%) ， 4-10$ 日 19 人 $(23 \%) ， 11-20$ 日 15 人 $(18 \%)$ と重篤な疾患の比率が 多い割には 20 日以内の入院患者が $85 \%$ を占めた (Table 6)。全 82 人の平均在院日数は 10.8 日であり， 同時期における当院の平均在院日数約 23 日に比して 短かった。これは多くの患者や家族が早期の退院帰
Table 6. Hospitalization.

\begin{tabular}{lcc}
\hline Days & No. & \\
\hline Less than 4 & 36 & $(44 \%)$ \\
$4-10$ & 19 & $(23 \%)$ \\
$11-20$ & 15 & $(18 \%)$ \\
$21-30$ & 7 & $(9 \%)$ \\
$31-60$ & 4 & $(5 \%)$ \\
More than 60 & 1 & $(1 \%)$ \\
\hline
\end{tabular}

Table 7. Condition during travel home.

\begin{tabular}{lc}
\hline Used medical apparatus & 13 \\
Wheelchair & 7 \\
Stretcher & 4 \\
Drip infusion and/or oxygen & \\
Attendance during travel & 12 \\
Doctor and nurse & 20 \\
Family or person concerned &
\end{tabular}

国を強く希望するために，医療側もこれに応えるべ く最大限の努力を行ったためと考えられる。

重篤な疾患にもかかわらず，早期の退院帰国を実 現させるために，病態不変のまま退院帰国した者が 10人にのぼった。また時に車椅子，ストレッチャー， 酸素などを使用した者があり，さらに病状や航空機 利用の条件から医師・看護婦が州国に付き添う必要 があった者が 12 人あった $($ Table 7)。このうち 3 人は 費用や日程などの面から患者側で付き添い医療ス タッフの手配ができず，当院のスタッフが現地まで 付き添う必要があった。

なお，医療費の支払い状況については，診療録上 の記載ではその詳細に関して全例で補足することは できなかったが，診療録から退院時に有効な医療保 険による支払いが確認された者は 10 人，医療保険を 持たず本人の支払能力がないため本人以外の関係者 （会社，空港警察，宗教組織など）による肩代わりに よる支払いが確認できた者が 8 人いた。患者の中に は70万円の医療費を，月々 5,000円ずつの分割で支 払うことを約束して帰国した者もあった。2000年度 1 年間に当救命救急センターに入院した外国人患者 の医療費については，会計課による年度末調査で請 
求額総額の約 $35 \%$ が未収であった。

\section{考察}

今回対象としたのは 1993 年から 2000 年までの間 に，当院救命救急センターで入院治療を行った 82 人 の患者である。

当院では一般外来に受診した者, 救急患者であっ ても軽症の者, 緊急性の少ない者などは, 救命救急 センター以外の一般病棟に入院している。また救急 外来での検査や投薬と注射のみで診療を終了する者 も多い。それらの中には外国人旅行者もしばしば含 まれる。したがって，当院全体でこの 8 年間に診療 した外国人旅行者は，おそらくこの数倍に及ぶもの と推定される。

今回の検討は当院救命救急センターへの入院を必 要とした患者のみを対象としており, 当院を受診し た外国人旅行者全般の救急疾病傾向をみたものでは ない。さらに新東京国際空港を利用した外国人旅行 者であっても空港周辺の他施設に入院した者もあっ たと考えられ，その意味で本稿に示された結果の意 味は限定的なものである。しかしながら，対象が時 間的制約の多い旅行者であることや言語によるコ ミュニケーションに困難があるため, 日常的な診療 体制では, 外来だけの診療で終わった者や, 併設病 院に直接入院した患者に関してまで十分な患者背景 情報などを得る時間的余裕はない。したがって，空 港を利用する外国人旅行者救急医療を全般的に調查 検討するためには，十分な外国語能力を持った医療 および事務スタッフの人数を確保した上で，関係施 設と共同で前向きの研究をする必要があると考えら れた。

今回対象とした 82 人の外国人旅行者の場合, 一般 の救命救急センター患者と同様, 緊急手術を要する 消化器疾患, 交通事故などによる頭部の外傷, 骨折, 心筋梗塞, 心不全, 呼吸不全といった急性の循環器. 呼吸器疾患, 脳血管障害などが多くみられた。これ は救命救急センターが取り扱った患者であるため, 旅行者であることや外国人であることによる疾患の
偏りがあまりなかったためと考えられる。ただし， 当院救急救命センターの一般患者に比して, ICU/ CCU入室率や死亡率が高く，旅行中にもかかわらず 重症で入院を余儀なくされた状況を反映していたも のと考えられる。また慢性呼吸不全の急性増悪にお いては, 旅行中の呼吸器感染, 航空機内の低い気圧 (0.8気圧)，および航空機内の空気の乾燥が原因と考 えられる者があった ${ }^{10,11) 。 ~}$

近年，いわゆる「エコノミークラス症候群」として 注目され話題となっている肺血栓塞栓症 ${ }^{12,13)}$ は今回 の患者群には含まれていなかった。この疾患は航空 機による旅行者では注意すべき疾患ではあるが，こ れまでの同症候群の欧米と本邦を合わせた報告例が 200 例足らずであり，元来それほど頻度の高い疾患 ではない14,15)。また開発途上国からの旅行者に注意 すべき輸入感染症は含まれていなかった。

国籍のみならずあらゆる面で多種多様な外国人旅 行者の救急入院診療においては, 診療に使う言語, 患者の早期帰国の希望とそのための配慮と手配，医 療費の支払い条件など，一般の日本人患者や国内在 住中の外国人と異なり，医学以外の社会的経済的問 題への対応に要する労力がきわめて大きい。

これらの点について, 調査した期間での経験を基 に，その問題点と当院で行った対策などを以下に論 じる。

第 1 に，24人が英語を話さなかったが，そればか りでなく来院時に後見人や保証人となるべき家族や 関係者が同伴している者が32人（39\%）のみであっ た。このことは救急医療で刻一刻変化する病態に あって, 診療に必須な病歴の聴取や病状説明, イン フォームドコンセントの取得などに非常に困難を生 じた。このような場合，付き添いの航空会社職員や 救急隊から得た不十分な情報だけで初期診療を開始 しなければならないこともあった。その上で大使館 や国外の家族に電話で連絡をとり，病歴を聞き，病 状を説明し，ファックスなどで医療情報を交換し， 場合により家族の来邦を要請するといったことも必 要であった。 
また，当院では成田市内に在住する英語，ドイッ 語，ロシア語，スペイン語，タイ語，韓国語などの 言語に通じた語学ボランティアを組織し，このよう なボランティアの都合のつく時間帯に来院してもら い，集中的に病歴聴取や病状説明，インフォームド コンセントの取得を行ったが，これは時にきわめて 有効なシステムであった。

救急病棟では, 語学ボランティアに依頼して各国 語の頻用対訳文パネルを作製し，看護上のコミュニ ケーションなどに利用した。このパネルは看護ス タッフにとっては，日常の看護の際に有用であった。

また，当院の医師，看護師，医療事務員には英語 を十分に話す者が少なく, 北米での看護経験のある 英語に堪能な看護師 1 名を外国人患者の専任とした。 この看護師と担当医や担当科管理医師とが協力して 問題の解決に当たる体制をとったが，医療費や帰国 に関する複雑な手続きへの対応，外国での不慣れな 入院生活に対応するきめ細かい配慮の面で, このシ ステムはいまなお外国人の診療上不可欠の存在と なっている。

第 2 に, 旅行中の外国人患者の救急診療において, ほとんど例外なく問題になるのは退院や帰国の時期 や方法の決定であった。患者は旅行の途中の罹患で あるため, 病状の軽重にかかわらず, 早期退院と早 期帰国を強く希望する者が多い。医療側の特例的扱 いの努力もあって入院期間は平均在院日数 10.8 日と きわめて短い。多くの外国人患者は，旅先での突然 の入院治療に旅行予定が遅れ，前後策がたたず混乱 している場合も多い。一方, 救急疾患においては数 日後の病態の変化を正確に予測できないこともまれ ではなく，帰国に際して一般の航空機を利用する場 合は，その利用にも条件が多く準備も煩雑となる16)。 このような諸条件を総合的に検討し, 最適の医療を 行い, かつ早期退院，早期帰国を実現するためには， 診療と平行して日々患者や, 時に海外にいる家族, 航空会社などと協議を重ねる必要があった。

近年, こうした国外における傷病者の帰国 (medical repatriation) を担当する, 航空医学や救急医
学に精通した専門医療組織がフランスのSAMUなど をはじめ海外には存在する17)。一方，わが国でも以 前からそのような組織の必要性が指摘されながらも, 実情は当院のような旅行者を多く扱う病院や, 関心 のある施設や医師により散発的に施行されているに 過ぎない18,19)。今後，ますます国際間の旅行が一般 化することを考えると, わが国でも旅行者を対象と した医療の発展と, 即応性のある国際医療搬送チー 厶の編成がなされ，海外の邦人や国内の外国人にも これを容易に利用できる制度が必要であると考えら れる。

最後に, 今回対象とした全患者については確認し 得なかったが，当センターに入院した旅行者には， 経済的に余裕のある者ばかりではなく, 旅行者保険 にも未加入の発展途上国からの移民の家族や，時に は密入国者などの犯罪者も含まれていたという問題 がある。

そのような場合であっても, 病院は人道上から救 急診療を拒否することはできない。したがって今回 のような調査に当たり, 病院が外国人旅行者に関し て行った経済的収支の検討は重要なテーマである。 一方で，外国人旅行者の医療費確保には様々な国内 制度の利用, 病院による医療費の減免, 海外の保険 会社による支払い，第三者による肩代わり，一時金 による帰国や分割払いなど，一般の保険請求とは異 なり，きわめて複雑で時に完済まで年余にわたる事 務処理が必要である。しかしこのような事務処理は 複雑でかつ特例的な場合が多く, 当院では個々の事 情が不明のまま未収金として処理されていることが 多かった。実際に今回調査した 82 人の患者すべてに ついての医療費の収納状況を会計資料からも調査を 試みたが，すでに一部の資料は保存されておらず検 討にたるデー夕を得ることはできなかった。今後こ のような業務を外国語で行える医事会計職員の育成 が必要であることも痛感した。ただし，2000年年度 末で, 2000年度分の外国人旅行者救急入院患者の医 療費は約35\%が未収金となっており，年度を越えて 支払われる部分があるとしても，病院にとって $20 \%$ 
から 30\%が未収金もしくは損金になっているものと 推定される。

また, 病院が行ってきた特例的医療や援助の内容 には担当職員の献身的努力や外国語による交渉能力 なども含み，一定の金額として計算できるものでは ない。しかも，むしろこれらの対応のほうが病院の 他の日常診療に及ほす影響は大きい場合が多々ある （治療以外の交渉や説明に連日長時間を要したり，急 な帰国決定に付き添うなどのため他の診療予定が果 たせなくなるなど)。

外国人旅行者の救急患者診療は, 現状ではそれほ ど数の多いものでなく, しばしば取り扱う病院はご く限られた地域の病院に過ぎない。しかしその緊急 性・特殊性は恐らく最も困難な医療形態のひとつで あると考えられる。今後さらに人的国際交流は進む と考えられ，例えば未保険外国人旅行者のための医 療費援助基金の新設，人材の面では医療帰省・医療 費請求に関し国内外との交渉を行える専門医療事務 員の育成などが必要であろう。国は国際交流の前線 でこうした医療を行っている病院に対して, 効果的 な行政的援助を検討すべきと考える。

\section{文献}

1）法務省大臣官房司法法制部編. 出入国管理統計年報. 第 40 (平成 13 年版). 財務省印刷局, 東京, 2001, p6-35.

2) Prazuck T, Semaille $C$, Halioua $B$, et al: Health hazards in international tourists visiting Paris in August: a five-year retrospective epidemiologic survey. J Travel Med $1998 ; 5$ : 178-83.

3) Cossar JH, Reid D, Fallon RJ, et al: A cumulative review of studies on travellers, their experience of illness and the implications of these findings. J Infect $1990 ; 21: 27-42$.

4）大越裕文, 大川康彦:航空機内での疾病予防. 診断と治 療 $2000 ; 88: 1332-6$.
5) Kramer MR, Jakobson DJ, Springer C, et al: The safety of air transportation of patients with advanced lung disease. Chest $1995 ; 108: 1292-6$.

6) Zahger D, Leibowitz D, Tabb IK, et al: Long-distance air travel soon after an acute coronary syndrome: a prospective evaluation of a triage protocol. Am Heart J $2000 ; 140$ : 241-2.

7）八木啓一，東平日出夫，山下太，他:空港より搬送され た外国籍患者に対する診療以外の問題点について．日臨 救急医会誌 $2000 ; 3: 97$.

8）吉田竜介, 大泉旭, 相星淳一, 他:外国人の救急医療に おける医療経済的問題点の検討. 日救急医会誌 2001； $12: 534$.

9）葉季久雄, 青木克憲, 堀進悟, 他: 外国人の救急医療, 特に不法滞在者についての考察. 日救急医会誌 2001； $12: 534$.

10) Aldrette JA, Aldrette LE: Oxygen concentrations in commercial aircraft flights. South Med J $1983 ; 76: 12-4$.

11）加藤啓一, 嚴康秀: 呼吸不全患者の航空機搬送の問題. 呼吸と循環 $1994 ; 42: 349-52$.

12) Eklof BO, Kinstner RL, Masuda EM, et al: Venous thromboembolism in association with prolonged air travel. Dermatol Surg $1996 ; 22: 637-41$.

13）森尾比呂志, 藤森義治, 寺沢公仁子, 他:航空機による 旅行中に発症した肺塞栓症の 14 例：エコノミークラス 症候群. 呼吸と循環 $2000 ; 48: 411-5$.

14）森尾比呂志：エコノミークラス症候群 (肺血栓塞栓症). 呼吸 $2000 ; 19: 1180-5$.

15) Lapostolle F, Surget V, Borron SW, et al: Severe pulmonary embolism associated with airtravel. N Engl J Med 2001 ; $345: 779-83$.

16）淺沼恵子：民間航空機による医療帰省の 1 症例：個人レ ベルでの医療帰省の問題点. ICUとCCU 1999;23:7859.

17）丸川征四郎，加藤啓一：フランスにおける医療帰省 (repatriation) の現状. 麻酔 $1990 ; 39: 1711-6$.

18）上田篤史, 三嶋秀行, 吉川宣輝, 他: 呼吸不全を合併し たAIDS患者の医療帰省 (航空搬送)。臨麻 $1998 ; 22$ ： 46-8.

19）須崎紳一郎, 小井土雄一, 冨岡譲二, 他：International repatriation（国際患者搬送帰還）の実際と問題点. 日救 急医会誌 $1994 ; 5: 42-50$. 


\author{
ABSTRACT \\ Masaaki Osegawa ${ }^{1}$, Hiroshi Morio ${ }^{2}$, Kazuhiro Nomoto ${ }^{3}$ \\ Masahiko Nishizawa ${ }^{4}$, and Tomohito Sadahiro ${ }^{1}$ \\ ${ }^{1}$ Narita Red Cross Hospital Emergency Center \\ ${ }^{2}$ Department of Internal Medicine, Narita Red Cross Hospital \\ ${ }^{3}$ Department of Neurosurgery, Narita Red Cross Hospital \\ ${ }^{4}$ Department of Surgery, Narita Red Cross Hospital
}

Present Medical Practice and Problems in Emergency Disease in Foreign Travelers Requiring Hospital Admission

Narita Red Cross Hospital is located near the New Tokyo International Airport and has many occasions to treat foreign travelers with acute severe illness. We retrospectively studied 82 such cases (50 men and 32 women, age 15-82 y/o, mean of age 47.7 y/o) admitted to the Narita Red Cross Hospital Emergency Center over 8 consecutive years (1993-2000). The number of patients from the U.S. was 31, the highest. Patients from East Asia numbered 29, and nations from which patients came numbered 22. Some 55 patients spoke English, but communication was the most serious problem in 24 who did not speak English. In these cases, it was almost impossible to take history, get informed consent, explain the disease, or understand complaints. Diseases included gastrointestinal disease (GI tract bleeding, perforation, ileus, acute appendicitis etc.) $22 \%$, cardiovascular disease (acute myocardial infarction, heart failure) $16 \%$, trauma 18\%, disease of central nervous system (cerebrovascular accident, epilepsy etc.) 15\%, respiratory disease (respiratory failure, pneumonia etc.) $7 \%$, other diseases $22 \%$. Eighteen patients $(22 \%)$ were treated in the ICU/CCU. Disease was treated in 62 cases, unchanged notably in 10 cases, and involving simple treatments were 3 cases. Overall, 7 died. Many wanted to be discharged and go home as soon as possible, admissions were relatively short. Patients admitted for less than 21 days numbered 70 cases $(85 \%)$. Twelve patients needed medical attendance (doctor and/or nurse) and 20 needed nonmedical assistance (family or a person concerned) for travel home. During travel, 13 patients required a wheelchair and 7 a stretcher. Such medical practice forces the hospital staff to make unusual efforts in verbal communication and in managing early repatriation. The hospital sustains some economic loss with patients without medical insurance. More effective support should therefore be considered by the administration.

(JJAAM $2002 ; 13: 703-10)$

Key Words : foreign traveler, emergency, airport

Received for publication on March 8, 2002 (02-021) 